\title{
Red blood cell alloimmunization and minor red blood cell antigen phenotypes in transfused Ghanaian patients with sickle cell disease.
}

Lilian A Boateng, ${ }^{1.2}$ Andrew D Campbell, ${ }^{3}$ Robertson D Davenport, ${ }^{4}$ Alex Osei-Akoto ${ }^{5}$, Sheri Hugan, ${ }^{4}$ Akwasi Asamoah ${ }^{1}$ and Henk Schonewille ${ }^{6}$

\footnotetext{
${ }^{1}$ Medical Laboratory Technology, Kwame Nkrumah University of Science and Technology, Kumasi, Ghana,

${ }^{2}$ International Public Health, Liverpool School of Tropical Medicine, Liverpool, UK,

${ }^{3}$ Paediatrics, George Washington School of Medicine and Health Sciences, Washington DC, USA,

${ }^{4}$ Blood Bank and Transfusion Services, University of Michigan Health Systems, Michigan, USA,

${ }^{5}$ Child Health, School of Medical Sciences, Kwame Nkrumah University of Science and Technology, Kumasi, Ghana,

${ }^{6}$ Department of Experimental Immunohematology, Sanquin, Amsterdam, Netherlands
}

Correspondence to: Lilian Antwi Boateng, lilian.boateng@lstmed.ac.uk

Competing interests: the authors have no competing interests.

Short running title: RBC antibodies in Ghanaian SCD patients

Word count: 2715

Contributors:

This is the author manuscript accepted for publication and has undergone full peer review but has not been through the copyediting, typesetting, pagination and proofreading process, which may lead to differences between this version and the Version of Record. Please cite this article as doi: $10.1111 / \operatorname{trf} .15197$

This article is protected by copyright. All rights reserved. 
LB, AC, RD and AO conceived and designed the study

LB, SH and AA performed the laboratory test and interpreted the results

LB and HS analyzed, interpreted the data and drafted the manuscript

All authors critically revised the manuscript for important intellectual content and gave final approval of the version to be published.

Funding: This study was funded by Science Technology Engineering and Mathematics (STEM) of the African Studies Centre, University of Michigan, USA.

Ethical approval: The study was approved by the Committee on Human Research, Publication and Ethics, Kwame Nkrumah University of Science and Technology. 


\section{ABSTRACT}

BACKGROUND: The routine pre-transfusion investigations in Southern Ghana involve only ABOD blood group typing and ABO compatibility testing without screening for irregular red blood cell antibodies. The prevalence and specificities of red blood cell antibodies and frequencies of most minor blood group antigens in transfused patients with sickle cell disease (SCD) in Ghana are not known and are the objectives of this study.

STUDY DESIGN AND METHODS: A cross-sectional study that investigated transfused patients with SCD for the presence of irregular RBC antibodies and Rhesus, Kell, Duffy, Kidd and Ss antigens.

RESULTS: From a total of 154 patients (median age, 9 years), ten patients (6.5\%) possessed 13 antibodies, predominantly against D, C and E antigens. In three patients, the antibodies (anti-D, anti$\mathrm{D}+\mathrm{C}$ and anti-C+e) were against antigens they possessed by serology. Genotyping showed that two of these patients had variant RHCE genes that encode for weak and partial e antigens and one patient had a partial $R H C$ gene.

Frequencies of most RBC antigens were comparable with frequencies established among the African American population, however, K-k- and Jk(a-b-) phenotypes were more frequent and were present in $21 \%$ and $17 \%$ of patients, respectively.

CONCLUSION: The prevalence of RBC alloimmunization in transfused Ghanaian patients with SCD was $6.5 \%$ and the majority of antibodies were against antigens of the Rh system. Our findings stress the need to include pre-transfusion testing for RBC antibodies in patients with SCD, to improve transfusion safety.

Key words alloimmunization, sickle cell disease, red blood cell antigens, blood transfusion, Ghana, Africa 


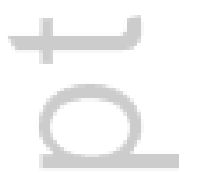

4 


\section{Introduction}

Sickle cell disease (SCD) is the most common monogenic disorder, with the greatest occurrence in sub-Sahara Africa (SSA). More than 75\% of SCD births are currently in SSA and has been predicted to rise to almost $90 \%$ by the year $2050 .{ }^{1}$ Death rate has been estimated at $50-90 \%$ for children with SCD in SSA before the age of 5 years. ${ }^{2}$ In Ghana, $2 \%$ of newborns have SCD and up to $30 \%$ carry the sickle cell gene. ${ }^{3}$ Most individuals with SCD in SSA are diagnosed when they present with symptoms (i.e. dactylitis, splenic sequestration) during childhood, at a mean age of two years. Although highly cost-effective, screening newborns for early detection and timely treatment of SCD is, contrary to the United States and many European countries, not routine in Ghana. ${ }^{4}$

Red blood cell (RBC) transfusions in SCD are used to improve oxygen-carrying capacity by correcting anemia, to suppress the production of sickle reticulocytes and to prevent or reverse complications related to vaso-occlusion and hemolysis. RBC transfusion has shown tremendous improvement in patients' wellbeing. ${ }^{5,6}$ However, RBC alloimmunization is a major complication in transfused patients with SCD and the frequency ranges from 2-63\%. ${ }^{7-14}$

The pathophysiology of RBC immunization is considered multifactorial. Besides the disparity in RBC antigens between donors and recipients, other contributory factors include sex, age, patients' age at first transfusion, exposure to episodic transfusions, patients' immune regulatory state and genetic status. $^{15-19}$

RBC alloimmunization may delay or even prevent blood transfusion, complicate pregnancies (i.e. hemolytic disease of the fetus and newborn) and increases the risk of delayed hemolytic transfusion reactions. ${ }^{20,21}$ In addition, alloimmunized patients have an increased risk of developing additional alloantibodies and autoantibodies. ${ }^{22-24}$

In Ghana, the main indications for RBC transfusions in patients with SCD are low hemoglobin (resulting mainly from RBC hemolysis and malaria) and acute crisis. There are little or no chronic 
transfusion programmes. The routine pre-transfusion investigations involve only ABO-D blood group typing and $\mathrm{ABO}$ compatibility testing (immediate spin cross-match) without screening for irregular RBC antibodies. Consequently, the frequency of most blood group antigens other than ABO-D and RBC alloimmunization in transfused patients with SCD in Ghana are not known.

We studied the prevalence and specificities of RBC antibodies and the frequencies of some common minor blood group antigens in transfused patients with SCD at Komfo Anokye Teaching Hospital, Kumasi, Southern Ghana.

\section{Materials and Methods}

\section{Patient recruitment}

In a cross-sectional study, patients with SCD were recruited, between January to November 2016, at the sickle cell clinic of the Komfo Anokye Teaching Hospital, (KATH), Kumasi, with approval from the Committee on Human Research, Publication and Ethics, Kwame Nkrumah University of Science and Technology. KATH is a 1200-bed hospital with approximately 17,000 transfusions annually, of which $80 \%$ is transfused as whole blood. Blood is sourced from both voluntary (80\%) and (family) replacement donors (20\%). Blood is neither irradiated nor leucoreduced before transfusion. The sickle cell clinic treats and transfuses approximately 5000 and 150 SCD patients annually, respectively. It has about 1000 transfused patients with SCD of which 600 have received up to four RBC transfusions.

The study inclusion criteria were: patients with SCD of any age and SCD genotype, with at least one RBC transfusion event and the last transfusion at least two weeks before enrollment into the study. Patients with the last transfusion at least two weeks before the time of enrollment were selected to allow a time window within which (new or boostered) antibodies might develop following 
transfusion. Informed consent was obtained from participants of 18 years and older and from guardians of those under 18 years of age.

\section{Data collection}

Participants' basic demographic characteristics, number of previous transfusions, age at first transfusion and indication for transfusion were retrieved from patients' hospital files and recorded on clinical record forms. Patients or their caretakers provided us with this information and transfusions in hospitals other than KATH, if missing from the hospital file. However, because patients' (or guardians') memory may not be exactly accurate, the number of transfusions were categorized as 1, 24 and $\geq 5$ RBC units.

\section{Sample processing and laboratory investigation}

Patients' blood samples were separated into RBC with buffy-coat and plasma. RBC antigen typing was performed at the Haematology Unit of KATH. Frozen RBC and plasma samples were transported to the University of Michigan Reference Laboratory, Michigan, for antibody screening and identification tests and molecular genotyping. Genotyping was performed when antibodies were present against antigens the patient possessed with serology.

\section{Red blood cell antigen and antibody investigations}

Serologic blood group antigen (D, C, c, E, e, K, k, Fy $\mathrm{F}^{\mathrm{a}} \mathrm{Fy}^{\mathrm{b}}, \mathrm{Jk}^{\mathrm{a}}, \mathrm{Jk}^{\mathrm{b}}, \mathrm{S}$ and s) typing was performed with commercially available antisera (Immucor, Inc., Norcross, GA; Ortho Clinical Diagnostics, Inc., Raritan, NJ), using the conventional tube method, according to the manufacturer's instructions.

RBC antibody screens were performed with the indirect antiglobulin technique (IAT), using a LISS gel test and a two-cell screen panel (Ortho Clinical Diagnostics, Inc., Raitan NJ). Antibody 
identification was performed on samples with a positive screen using a 12-cell panel by the same technique. Antibody specificities that could not be identified with the LISS technique were subjected to further gel column agglutination testing with enzyme (ficin) treated panel cells.

Frozen RBC samples from patients with antibodies to antigens they typed positive for by serology were sent to Grifols Immunohematology Center, USA for genotyping using the BLOODchip ID CORE XT v.4.0, BID XT software, Allele-Specific PCR and Sanger DNA sequencing. ${ }^{25}$

\section{Statistical analysis}

Median and range described non-normally distributed continuous variables. Univariate logistic regression was used to determine the association of patient characteristics, i.e. sex, age at enrollment (continuous), age at first transfusion (categorized as $\leq 1,2-5$, 6-9 and $\geq 10$ ), SCD genotype (SS and other), ethnicity (Akan and other) and number of transfused units (categorized as 1, 2-4 and $\geq 5$ ), with the presence of antibodies. Results are presented as odds ratios (OR) with 95\% confidence intervals (CI). A p-value $<0.05$ was considered statistically significant. Statistical analyses were performed using the Statistical Package for the Social Sciences (SPSS Inc, Chicago, IL, USA).

\section{Results}

A total of 154 patients with SCD (male to female ratio, 1.3; median age 9; range 1-50 years) were recruited. Patients were mainly from the Akan tribe (81\%) and $87 \%$ had the SCD SS genotype. The transfusion history revealed that 32\% of patients had received one RBC unit, 55\% received 2-4 units and $12 \%$ more than four RBC units. While $23 \%$ of patients received the first $\mathrm{RBC}$ transfusion during the first year of live, only 7\% did so at or after age ten (Table 1).

In ten patients (6.5\%; 95\% CI, 3.3-11.9\%), antibody screening was positive and identification revealed 13 RBC antibodies. Nine antibodies were against antigens in the Rh system, three against the 
$\mathrm{M}$ antigen and one against a low frequency antigen of unknown specificity. Three patients had multiple antibodies against Rh system antigens (Table 2). In three patients, the antibodies (anti-D, anti-D+C and anti-C+e) were against antigens they possessed by serology. Genotyping showed that the two serologically $\mathrm{D}+$ male patients had $R H D^{*}$ deletion and variant $R H C E$ genes that encode for weak and partial RHe antigens. The patient with anti-C+e had partial $R H C$ and normal $R H e$ genes (Table 2).

Univariate logistic regression revealed that age at enrollment, age at first transfusion, SCD genotype and ethnicity were not associated with the presence of antibodies. Alloimmunization showed a trend to be lower in females compared to males (OR, 0.30; 95\% CI 0.06-1.48; p=0.14) and was significantly associated with the number of transfused units (OR 2.87; 95\% CI 1.02-8.08; $\mathrm{p}=0.046$ ) (Table 3). The frequency of patients with antibodies increased from $2 \%$ in the 50 patients who had received only one unit, to $7 \%$ in 85 patients with 2-4 units and $16 \%$ in 19 patients with more than four RBC units. In multivariate analysis, including sex and number of transfusion, only the number of transfusions was associated with the presence of antibodies (aOR 2.87; 95\% CI 1.02-8.08; $\mathrm{p}=0.046$ ).

Due to limited reagent availability, serologic RBC antigen typing was performed in 78 to 133 patients. The $\mathrm{D}$, c, e and s antigens were present in more than $90 \%$ of patients, $\mathrm{k}$ and $\mathrm{Jk}^{\mathrm{a}}$ in about 75\%, A, B, C, E, $\mathrm{Jk}^{\mathrm{b}}$ and $\mathrm{S}$ in $24-47 \%$ and $\mathrm{Fy}^{\mathrm{a}}$, $\mathrm{Fy}^{\mathrm{b}}$ and $\mathrm{K}$ antigens in less than $5 \%$ of patients (Table 4). The Fy(a-b-) phenotype was present in $92 \%$ of the $116 \mathrm{Fy}^{\mathrm{a}}$ and $\mathrm{Fy}^{\mathrm{b}}$ typed patients and the S-sphenotype in $0.9 \%$ of $107 \mathrm{~S}$ and s typed patients. The K-k- phenotype was present in $21 \%$ of $71 \mathrm{~K}$ and $\mathrm{k}$ typed patients and the $\mathrm{Jk}(\mathrm{a}-\mathrm{b}-)$ phenotype in $17 \%$ of $126 \mathrm{Jk}^{\mathrm{a}}$ and $\mathrm{Jk}^{\mathrm{b}}$ typed patients (Supplemental Table 1, including an overview of studies on RBC antigen phenotypes in other Ghanaian ethnicities and published in African Americans). None of the patients with the K-k- and the Jk(a-b-) phenotypes were known family members. 


\section{Discussion}

This cross-sectional study, conducted in Southern Ghana, which recruited 154 transfused patients with SCD, predominantly children from the Akan tribe, revealed an alloimmunization prevalence of $6.5 \%$. The number of transfused units was associated with the presence of antibodies. The majority of antibodies were against antigens from the Rh blood group system. To the best of our knowledge, this is the first study reporting on the prevalence and nature of RBC antibodies in transfused patients with SCD in Ghana. In our previous study, 9.4\% of 106 patients, predominantly transfused adults with other diseases from the same area in Ghana, were alloimmunized. ${ }^{26}$ A meta-analysis comprising eleven studies from SSA, and mainly in transfused patients of various ages with SCD, showed that 6.7\% (95\% CI 5.7-7.8\%) had clinically significant RBC alloantibodies. Antibodies against Rh antigens were the most prevalent, comparable with our results. ${ }^{27}$ The alloimmunization prevalence observed in our study is consistent with the $2.9-6.1 \%$ established in other studies, that were performed in (predominantly) children with SCD from other SSA countries. ${ }^{7-10,28}$

The frequency of patients with antibodies in our study increased from $2 \%$ after one RBC unit to $16 \%$ in patients who had received more than four units. Previous studies showed a higher risk for alloantibodies with increasing number of transfused RBC units in patients with and without SCD. ${ }^{12,29-}$

${ }^{31}$ Since patients with SCD are lifelong transfusion dependent, preventive extended RBC antigen matching, especially for $\mathrm{C}$ and $\mathrm{E}$ antigens, should be considered. A study exploring Rh blood group antigen frequencies among 1533 blood donors from the Akan tribe, found C and E antigens less frequent compared to our patients with SCD (19\% vs $37 \%$ and $17 \%$ vs $28 \%$, respectively). ${ }^{32}$ The ccee phenotype was present in $65 \%$ and $82 \%$ of the $\mathrm{D}+$ and $\mathrm{D}$ - donors, respectively, suggesting that matching for $\mathrm{C}$ and $\mathrm{E}$ antigens is feasible. However, considering that 1) homozygous serologic expression of $\mathrm{C}$ or $\mathrm{E}$ antigens was only present in none and two of our patients, respectively, 2) the frequent presence of $R H$ variant alleles in Blacks and 3) most of our patients received transfusion for 
unplanned emergencies, a more pragmatic approach would be to transfuse all patients with SCD with C and E negative RBC. ${ }^{33,34}$ This will require a pool of $\mathrm{C}$ and $\mathrm{E}$ antigen typed donors, which will be challenging in Ghana.

Three patients had anti-M, which is often naturally occurring, usually of IgM type, relatively common in children (with and without SCD), may appear in response to an infection and is often clinically insignificant. ${ }^{35,36}$ However, transfusion reactions due to anti-M reactive at $37^{\circ} \mathrm{C}$ have been reported and patients with warm-reacting anti-M should receive M- RBCs. ${ }^{37,38}$

One patient had anti-D and one anti-C+D, but tested both $\mathrm{D}+$ by serology. Genotyping revealed $R H D^{*}$ deletions, absence of C-alleles and variant e-alleles (ce(48C) and ceAG)) in both, the latter frequently present in African-Americans. ${ }^{39}$ A number of variant Rhce proteins such as ceCF, ceRT and ceSL carry D-specific amino acids or express D-like epitopes that can react with some monoclonal anti-D. ${ }^{40}$ For ceAG, this has not been described, so incorrect serologic D typing cannot be ruled out. The $\mathrm{C}+\mathrm{e}+$ patient with anti-C and auto- or e-like antibody had a $R H C$-variant allele, serologically detectable by some anti-C reagents.

Frequencies of most RBC antigens in our patients were comparable to those published in a text book for the Black, mainly African American, population. ${ }^{41}$ Frequencies of k (78\% and 100\%), $\mathrm{Fy}^{\mathrm{b}}$ (4\% and 23\%) and $\mathrm{Jk}^{\mathrm{a}}$ antigens (75\% and 92\%) were markedly lower, reflecting differences in the frequencies of some RBC antigens between predominantly Akan patients with SCD and the Black population. Our finding that $17 \%$ of our patients had the Jka(a-b-) phenotype is in accordance with the study by Acquaye who reported a Jk(a-b-) phenotype in $13 \%$ of 121 Southern Ghanaian donors from Ewe ethnicity. ${ }^{42}$ In addition, this phenotype was found in 38\% of 158 Ghanaian donors from Ga ethnicity and in $87 \%$ of 162 pregnant women from various ethnicities in Western Nigeria, further stressing that blood group prevalence can vary substantially among African ethnicities. ${ }^{43,44}$ So far, more than 40 variant Kidd alleles have been described in many different ethnic groups. These variants 
can silence protein expression or produce weak or partial antigens, hampering serologic typing. ${ }^{45}$ The high frequency of the K-k- phenotype in our patients is a novel finding. Similar to Kidd, more than 40 variant $K E L$ alleles lead to the $\mathrm{K}_{0}$ phenotype or reduced expression of Kell glycoprotein, termed Kmod phenotype. ${ }^{46}$ Only a few studies determined the frequency of Kell system blood groups in SSA populations and almost all were limited to the K-antigen. The frequency of k-antigen is largely unknown, but presumed to reach almost 100\%. Blood group antigen frequencies quoted for Blacks are often based on African Americans and obviously do not reflect distributions in African regions. For instance, the $\mathrm{Kp}^{\mathrm{b}}$ antigen from the Kell blood group system is, like k-antigen, presumed a high frequency antigen almost universally present on RBCs. However, a study from Cote d'Ivoire showed that $17 \%$ of 651 blood donors had the Kp(a-b-) phenotype. ${ }^{47}$ These novel findings deserve further explorations, including genotyping to determine the molecular basis of these phenotypes, but financial restraints prohibited this in our study.

Pre-transfusion investigations in Ghana are limited to ABO-D blood group typing and ABO compatibility testing. Little is known on the risk of transfusion reactions in patients with SCD receiving not completely cross-matched transfusions in SSA and transfusion reactions were not recorded in our study. However, in a one-year study in our hospital in 372 patients without SCD, the prevalence of acute (within 24 hours after transfusion) hemolytic transfusion reactions was 9.3 per 1000 transfusions. ${ }^{48}$ None of the reactions were attributable to ABO incompatibility, but the presence of irregular RBC antibodies was not investigated and cannot be ruled out as having been implicated.

Our study had several limitations. First, despite our thoroughness of investigation, demographic and transfusion information were not completely available for all patients, due to suboptimal hospital documentation. In addition, transfusion history may be impaired because patients' (or guardians') memory may not be exactly accurate. Second, the optimal period after transfusion for antibody detection is largely unknown, therefore our antibody screening might have been too soon 
after the last transfusion to detect new antibodies or too late resulting in evanescence of antibodies. ${ }^{49}$ Both result in an underestimation of antibody frequency. Also, because the actual number of RBC units before antibodies were formed were not known, - cross-sectional study design and patients might have been transfused in other hospitals -, the precise immunization rate per transfused unit could not be determined. Lastly, the study consisted of patients predominantly from the Akan tribe and results may not be generalizable for patients with SCD from other ethnic groups in Ghana.

In conclusion, the prevalence of RBC alloimmunization in transfused patients with SCD in Southern Ghana was $6.5 \%$ and alloantibodies were in the majority of cases against D, C and E antigens.

Our findings stress the need to test for the presence of RBC antibodies in SCD patients before transfusion, preferably using a standardized red cell-panel of 'African origin' (i.e. expressing V, VS and $\mathrm{Js}^{\mathrm{a}}$ antigens), but at least by performing an indirect antiglobulin compatibility test with donor RBC and patient serum to improve transfusion safety. The latter is probably cheaper and easier to implement in Ghana. However, to effectively improve safety, knowledge on blood group antigen frequencies in ethnic groups in SSA, RH genotyping and (limited) antigen matching may be essential in the future.

\section{ACKNOWLEDGMENTS}

The authors express their sincerest gratitude to the University of Michigan transfusion reference lab for donating RBC antisera for antigen typing and Imelda Bates for critically reviewing the manuscript. We also acknowledge Adam Mahe Mohammed, Francis Abban, Harrison Eyison and Edward Afriyie for supporting recruitment of study participants 


\section{References}

1 Piel FB, Hay SI, Gupta S, et al. Global burden of sickle cell anaemia in children under five, 20102050: modelling based on demographics, excess mortality, and interventions. PloS Med 2013;10:e1001484.

2 Makani J, Ofori-Acquah SF, Nnodu O, et al. Sickle cell disease: new opportunities and challenges in Africa. ScientificWorldJournal 2013;2013:193252.

3 Ohene-Frempong $\mathrm{K}$, Oduro J, Tetteh $\mathrm{H}$, et al. Screening newborns for sickle cell disease in Ghana. Pediatr 2008;121(suppl 2):S120-S121.

4 Kuznik A, Habib AG, Munube D, et al. Newborn screening and prophylactic interventions for sickle cell disease in 47 countries in sub-Saharan Africa: a cost-effectiveness analysis. BMC Health Serv Res 2016;16:304.

5 Lee MT, Piomelli S, Granger S, et al. Stroke Prevention Trial in Sickle Cell Anemia (STOP): extended follow-up and final results. Blood 2006;108:847-852.

6 Wahl S, Quirolo KC. Current issues in blood transfusion for sickle cell disease. Curr Opin Pediatr 2009;21:15-21.

7 Natukunda B, Schonewille H, Ndugwa C, et al. Red blood cell alloimmunization in sickle cell disease patients in Uganda. Transfusion 2010;50:20-25.

8 Mangare C, Mbugua A, Maturi P, et al. Red cell allo- and autoimmunisation in transfused sickle cell and cancer patients in Kenyatta National Hospital, Nairobi, Kenya. Afr J Lab Med 2015;4:297.

9 Eldour AAA, Ismail ME, Osman T, et al. Red cell alloimmunization in blood transfusion dependent patients with sickle cell disease in El-Obied city, Sudan. IOSR-JDMS 2015;14:137141. 
10 Meda E, Magesa PM, Marlow T, et al. Red blood cell alloimmunization in sickle cell disease patients in Tanzania. East Afr J Public Health 2014;11:775-780.

11 Abbas M, Bolad A, Jiefri N, et al. Red blood cell alloimmunization among Sudanese homozygous sickle cell disease patients. Am J Med Medical Sci 2013;3:61-67.

12 Sekongo YM, Kouacou APV, Kouamenan GS, et al. Anti-erythrocyte allo-immunization to sickle cell disease patients followed in transfusion therapy unit of the National Blood Transfusion Center of Abidjan Côte D’Ivoire. Int J Immunol 2017;5:1-4.

13 Akre DP, Seka-Seka J, Dasse SR, et al. Alloimmunisation anti-erythrocytaire post transfusionnelle chez les drepanocytaires suvis au Chu de Cocody Abidjan. J Sci Pharm Biol 2008;9:64-70.

14 Ugwu NI, Awodu OA, Bazuaye GN, et al. Red cell alloimmunization in multi-transfused patients with sickle cell anemia in Benin City, Nigeria. Niger J Clin Pract 2015;18:522-526.

15 Sins JWR, van den Bersselaar SM, Heijboer H, et al. Early occurrence of red blood cell alloimmunization in patients with sickle cell disease. Am J Hematol 2016;91:763-769.

16 Murao M, Viana MB. Risk factors for alloimmunization by patients with sickle cell disease. Braz J Med Biol Res 2005;38:675-682.

17 Sippert EÂ, Gilli SCO, Addas-Carvalho M, et al. Red blood cell alloimmunization in patients with sickle cell disease: correlation with HLA and cytokine gene polymorphisms. Transfusion 2017;57: 379-389.

18 Oliveira VB, Dezan MR, Gomes FCA, et al. -318C/T polymorphism of the CTLA-4 gene is an independent risk factor for RBC alloimmunization among sickle cell disease patients. Int $\mathrm{J}$ Immunogenet 2017;44:219-224.

19 Tatari-Calderone Z, Tamouza R, Le Bouder GP, et al. The association of CD81 polymorphisms with alloimmunization in sickle cell disease. Clin Dev Immunol 2013;2013:937846. 
20 Ngô C, Kayem G, Habibi A, et al. Pregnancy in sickle cell disease: maternal and fetal outcomes in a population receiving prophylactic partial exchange transfusions. Eur J Obstet Gynecol Reprod Biol 2010;152:138-142.

21 Chadebech P, Habibi A, Nzouakou R, et al. Delayed hemolytic transfusion reaction in sickle cell disease patients: evidence of an emerging syndrome with suicidal red blood cell death. Transfusion 2009;49:1785-1792.

22 Garratty G. Autoantibodies induced by blood transfusion. Transfusion 2004;44:5-9.

23 Young PP, Uzieblo A, Trulock E, et al. Autoantibody formation after alloimmunization: are blood transfusions a risk factor for autoimmune hemolytic anemia? Transfusion 2004;44:67-72.

24 Schonewille H, van de Watering LM, Loomans DS, et al. Red blood cell alloantibodies after transfusion: factors influencing incidence and specificity. Transfusion 2006;46:250-256.

25 López M, Apraiz I, Rubia M, et al. Performance evaluation study of ID CORE XT, a high throughput blood group genotyping platform. Blood Transfus. 2018;16:193-199.

26 Boateng LA, Schonewille H, Sackey B, et al. Prevalence of red blood cell antibodies among transfused patients at Komfo Anokye teaching (Kath) hospital, Ghana. JUST (Ghana) 2014;3:2734.

27 Ngoma AM, Mutombo PB, Ikeda K, et al. Red blood cell alloimmunization in transfused patients in sub-Saharan Africa: A systematic review and meta-analysis. Transfus Apher Sci 2016;54:296302.

28 Abbas M, Bolad A, Jiefri N, et al. Red blood cell alloimmunization among Sudanese homozygous sickle cell disease patients. Am J Med Med Sci 2013;3:61-67

29 Zalpuri S, Zwaginga JJ, le Cessie S, et al. Red-blood-cell alloimmunization and number of redblood-cell transfusions. Vox Sang. 2012;102:144-149 
30 Batina Agasa S, Dupont E, Kayembe T, et al. Multiple transfusions for sickle cell disease in the Democratic Republic of Congo: the importance of the hepatitis C virus. Transfus Clin Biol. $2010 ; 17: 254-259$

31 Siransy LK, Romualde DS, Richard Yeboah R, et al. Immune status and red cell alloimmunization among SCD patients in Côte d’Ivoire. J Clin Exp Immunol 2018;3:1-6

32 Acquaye J. ABO, Rhesus and Kell blood groups in the Akans of Ghana. Ghana Med J 2004;38:68-71.

33 Tournamille C, Meunier-Costes N, Costes B, et al. Partial C antigen in sickle cell disease patients: clinical relevance and prevention of alloimmunization. Transfusion 2010;50:131-9.

34 Chou ST, Jackson T, Vege S, et al. High prevalence of red blood cell alloimmunization in sickle cell disease despite transfusion from Rh-matched minority donors. Blood 2013;122:1062-1071.

35 Allali S, Cohen JF, Chalumeau M, et al. Prevalence and risk factors for red blood cell alloimmunization in 175 children with sickle cell disease in a French university hospital reference centre. Br J Haematol 2017;177:641-647.

36 Das R, Dubey A, Agrawal P, et al. Spectrum of anti-M: a report of three unusual cases. Blood Transfus 2014;12:99-102.

37 Sancho JM, Pujol M, Fernández F, et al. Delayed haemolytic transfusion reaction due to anti-M antibody. Br J Haematol 1998;103:268-269.

38 Alperin JB, Riglin H, Branch DR, et al. Anti-M causing delayed hemolytic transfusion reaction. Transfusion 1983;23:322-324.

39 Westhoff CM, Vege S, Hipsky CH, et al. RHCE*ceAG (254C $>\mathrm{G}$, Ala85Gly) is prevalent in blacks, encodes a partial ce-phenotype, and is associated with discordant RHD zygosity. Transfusion 2015;55:2624-2632. 
40 Westhoff CM. The structure and function of the Rh antigen complex. Semin hematol 2007;44:4250.

41 Reid ME, Lomas-Francis C, Olsson ML. The blood group antigen factsbook. [electronic book]: Oxford : Academic, 2012, 3rd ed.

42 Acquaye JK. Red cell antigens in the Ewe ethnic group of Ghana. Ghana Med J 1992;26:438-47.

43 Acquaye JK. Red cell antigens in the Ga ethnic group of Ghana. Ghana Med J 1990;24:177-182.

44 Erhabor O, Hassan M, Alhaji YB, et al. Kidd blood group phenotypes among pregnant women in Sokoto, North Western Nigeria. Asian Pac J Trop Med 2014;7(Suppl 1):S111-S115.

45 Lawicki S, Covin RB, Powers AA. The Kidd (JK) blood group system. Transfus Med Rev 2017;31:165-172.

46 ISBT. Names for Kell (ISBT 006) blood Group Alleles.

http://www.isbtweb.org/fileadmin/user_upload/files-

2015/red\%20cells/blood\%20group\%20allele\%20terminology/allele\%20tables/006\%20KEL\%20A

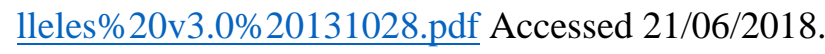

47 Siransy Bogui L, Dembele B, Sekongo Y, et al. Phenotypic profile of Rh and Kell blood group systems among blood donors in Cote d'Ivoire, West Afr. J Blood Transfus 2014;2014:309817.

48 Owusu-Ofori AK, Owusu-Ofori SP, Bates I. Detection of adverse events of transfusion in a teaching hospital in Ghana. Transfus Med 2017;27:175-180.

49 Williams LA 3rd, Lorenz RG, Tahir A, et al. High percentage of evanescent red cell antibodies in patients with sickle cell disease highlights need for a national antibody database. South Med J 2016;109:588-591.

This article is protected by copyright. All rights reserved. 
TABLE 1. Demographic and transfusion characteristics of the 154 transfused patients with sickle cell disease in Southern Ghana.

\begin{tabular}{|c|c|c|}
\hline Characteristic & Alloimmunized & Not alloimmunized \\
\hline Number of patients (\%) & $10(6.5)$ & 144 (93.5) \\
\hline Males / Females & $80 / 20 *$ & $55 / 45$ \\
\hline Median age at enrollment in years (range) & $8(2-22)$ & $9(1-50)$ \\
\hline Sickle cell disease genotype: SS / other & $90 / 10$ & $87 / 13$ \\
\hline Ethnicity: Akan tribe / Others & $80 / 20$ & $81 / 19$ \\
\hline Age at first transfusion $\dagger: \leq 1 / 2-5 / 6-9$ / & $30 / 30 / 30 / 10$ & 23 / 46 / 24 / 7 \\
\hline \multicolumn{3}{|l|}{$\geq 10$} \\
\hline Number of transfused units: 1 / 2-4 / $\geq 5$ & 10 / 60 / 30 & 34 / 55 / 11 \\
\hline
\end{tabular}

Date expressed as percentages, unless stated otherwise.

*The two females with antibodies were 6 and 13 years of age.

†Data available for 127 of 144 (88\%) not alloimmunized patients. 
TABLE 2. Red blood cell alloantibody specificities and Rh antigen serology and genotyping results in the ten alloimmunized patients with sickle cell disease in Southern Ghana

\begin{tabular}{|c|c|c|c|c|}
\hline Antibody & & & D, C, c, E and e pheno- and genoty & pes \\
\hline specificity & $\mathrm{N}$ & Serology & Genotyping & Predicted phenotype \\
\hline $\mathrm{M}$ & 3 & n.a. & n.a. & n.a. \\
\hline $\mathrm{D}$ & 1 & D-, C-, c+, E-, e+ & n.a. & n.a. \\
\hline $\mathrm{D}$ & 1 & $\mathrm{D}^{+}, \mathrm{C}-, \mathrm{C}^{+}, \mathrm{E}-, \mathrm{e}^{+}$ & $\begin{array}{l}\text { Homozygous } R H D^{*} \text { deletion, } \\
\text { Homozygous } R H C E^{*} c e A G\end{array}$ & D-, C-, E-, c+, partial-e \\
\hline $\mathrm{E}$ & 1 & $\mathrm{D}^{+}, \mathrm{C}-\mathrm{c}^{+}, \mathrm{E}-, \mathrm{e}^{+}$ & n.a. & n.a. \\
\hline $\mathrm{D}+\mathrm{C}$ & 1 & $\mathrm{D}^{+}, \mathrm{C}+, \mathrm{c}^{+}, \mathrm{E}-, \mathrm{e}^{+}$ & $\begin{array}{l}\text { Homozygous } R H D^{*} \text { deletion } \\
R H C E^{*} c e(48 C) \text { and } R H C E^{*} c e A G\end{array}$ & D-, C-, E-, c+, weak-e/partial-e \\
\hline C+e-like & 1 & $\mathrm{D}^{+}, \mathrm{C}+, \mathrm{c}^{+}, \mathrm{E}-, \mathrm{e}^{+}$ & $\begin{array}{l}\text { RHD*deletion and } R H D^{*} \text { 's } \\
\text { RHCE*ce and } R H C E^{*} c e[733 G, 1006 T]\end{array}$ & D-, partial-C, E-, c+, e+ \\
\hline $\mathrm{E}+\mathrm{C}^{\mathrm{w}}$ & 1 & $\mathrm{D}^{+}, \mathrm{C}-, \mathrm{C}^{+}, \mathrm{E}-, \mathrm{e}^{+}$ & n.a. & n.a. \\
\hline LFA $†$ & 1 & n.a. & n.a. & n.a. \\
\hline
\end{tabular}

N, number; n.a., not applicable.

$\dagger$ Antibody against an unknown low frequency antigen.

This article is protected by copyright. All rights reserved. 
TABLE 3. Univariate analysis of variables associated with the presence of RBC antibodies in 154 transfused patients with sickle cell disease in Southern Ghana.

\begin{tabular}{lccc}
\hline Characteristic & OR & 95\% CI & p-value \\
\hline Sex (male* vs female) & 0.30 & $0.06-1.48$ & 0.14 \\
Sickle cell disease genotype (SS* vs other) & 0.73 & $0.09-6.10$ & 0.77 \\
Ethnicity (Akan* vs other) & 1.08 & $022-5.39$ & 0.92 \\
Age at first transfusion $\dagger(\leq 1,1-5,6-9$ and $\geq 10)$ & 1.07 & $0.51-2.42$ & 0.86 \\
Age at enrollment (continuous) & 1.01 & $0.91-1.12$ & 0.82 \\
Number of transfused units (1, 2-4 and $\geq 5)$ & 2.87 & $1.02-8.08$ & 0.046 \\
\hline
\end{tabular}

*The reference.

†Data was available for 127 of 144 (88\%) not alloimmunized patients.

In multivariate analysis, including sex and number of transfused units, only the number of transfused units was associated with the presence of antibodies (aOR 2.87; 95\% CI 1.02-8.08; $\mathrm{p}=0.046$ ). 
TABLE 4. Frequencies of minor red blood cell antigens in patients with sickle cell disease from Southern Ghana.

\begin{tabular}{|c|c|c|c|c|c|}
\hline $\begin{array}{l}\text { RBC } \\
\text { antigen }\end{array}$ & $\begin{array}{c}\text { Number of } \\
\text { patients tested }\end{array}$ & $\begin{array}{c}\text { Antigen } \\
\text { frequency (\%) }\end{array}$ & $\begin{array}{l}\text { RBC } \\
\text { antigen }\end{array}$ & $\begin{array}{c}\text { Number of } \\
\text { patients tested }\end{array}$ & $\begin{array}{c}\text { Antigen } \\
\text { frequency (\%) }\end{array}$ \\
\hline $\mathrm{A}^{*}$ & 129 & 33 & $\bar{K}$ & 105 & 0 \\
\hline $\mathrm{B}^{*}$ & 129 & 24 & $\mathrm{k}$ & 78 & 78 \\
\hline D & 132 & 96 & $\mathrm{Fy}^{\mathrm{a}}$ & 116 & 4.3 \\
\hline C & 133 & 37 & $\mathrm{Fy}^{\mathrm{b}}$ & 133 & 3.8 \\
\hline $\mathrm{E}$ & 132 & 28 & $\mathrm{Jk}^{\mathrm{a}}$ & 132 & 75 \\
\hline c & 133 & 100 & $\mathrm{Jk}^{\mathrm{b}}$ & 127 & 47 \\
\hline \multirow[t]{2}{*}{ e } & 133 & 99 & $S$ & 118 & 39 \\
\hline & & & $\mathrm{s}$ & 116 & 94 \\
\hline
\end{tabular}

*ABO blood group frequencies were: O 50\%, A 26\%, B 17\% and AB 7\%. 